\title{
Global Youth Unemployment and Localized Impact: A Career Studies Teacher's Story
}

\author{
Lorraine Godden \\ Queen's University
}

\begin{abstract}
The global economic downturn and high youth unemployment have created a challenging context for Ontario secondary-school teachers to meet the compulsory half-credit career studies course objectives intended to support school-to-work (STW) transition. Bronfenbrener's (1979) ecological systems theory provided a clear framework to examine influences and knowledge one teacher used to support the teaching of career studies. The data showed that the teacher knew her local economy had been affected by the global economic downturn, and she described local business closures and the potential impact upon employment opportunities. The teacher understood the impact upon her students and explained the importance of students understanding these connections. The open level of the career studies course necessitated the meeting of diverse student needs, including students with disabilities, widely ranging academic levels, and those at risk. This study aids our understanding of how the GLC20 teacher might contribute to successful STW transition for all students in times of global high youth unemployment.
\end{abstract}

Navigation toward employment can be particularly challenging for young people. Even before the global economic downturn that began in 2008 (Organisation for Economic Cooperation and Development, 2009), youth (aged 15-24) worldwide were facing high levels of unemployment. In Canada the youth unemployment level was up to twice as high as that of adults (Quintini, Martin, \& Martin, 2007). Although many Organisation for Economic Co-operation and Development (OECD) countries including Canada are now experiencing economic recovery, the prospects for young people in the foreseeable future are still gloomy, with many unemployed youth likely to experience a prolonged period of joblessness (Scarpetta, Sonnet, \& Manfredi, 2010). 
Canada is one of the few G7 countries that entered the current global economic downturn with a relatively strong domestic economy (Department of Finance Canada, 2010). Nevertheless, the current Canadian government has introduced new policy initiatives in response to the global economic downturn. In one of its responses, the government has stated that the future success of Canada's economy depends on a skilled and educated workforce, and that Canada shines as an example of what can be achieved when people work together and combine the best of intellectual and natural resources to create jobs, growth, and opportunity (Prime Minister Stephen Harper's Mission Statement; see Harper, 2010). The global economic downturn has generated openings for the leaders of many nations, including Canada, to offer stimulus initiatives that aim to improve the working prospects of citizens, including those of youth. Such initiatives can present a dynamic and complex milieu for educators seeking to support youth with school-to-work transitions.

Career guidance is frequently seen as a facilitative method that can help to prepare young people for life beyond secondary school. Career guidance for school-age students can play a vital role in helping young people achieve skills, qualifications, and experience that develop their understanding of the world of work and of the economy (McCarthyFry, 2009). The global economic downturn and high youth unemployment have created a challenging context for the secondary-school teacher to meet career guidance objectives intended to support school-to-work (STW) transition. How well the career guidance teacher understands demographics, the distribution of occupations in the economy, federal and provincial economic and employment initiatives, and current labour market status can affect how well he or she supports individual students to connect their learning and skills to current labour market needs and opportunities. Therefore, it becomes vitally important to understand how a teacher of career guidance courses responds to the impact of global high youth unemployment at localized level to support students' STW transition.

The Canadian province of Ontario is home to over 2.8 million children and youth aged $0-18$, and approximately 135,000 children are born into the province each year (Ontario Ministry of Children and Youth Service, 2008). For young people in Ontario, the impact of the global economic downturn and its subsequent effect on job prospects are significant. Many small rural towns in eastern Ontario have been particularly affected; for example, in one town the impact of the economic downturn has been substantial, with the loss of 1,700 jobs over the past three to four years. When measured against a population of 9,000 residents, these are noteworthy job losses (Kelly, 2010).

I commence this article with a definition of key terms and the study's purpose. I then discuss the international and Canadian (federal and provincial) contexts that frame the teaching of career guidance courses. Subsequently, I review how the structure and outcomes of career guidance present a particular challenge in meeting the diverse and often specific needs of youth. I also review studies that specifically describe the career guidance courses in Ontario, where this study was conducted. The method employed for this study is described together with a discussion of findings with implications for policy and practice. 


\section{Definition of Terms}

\section{Career Guidance}

The OECD has defined career guidance as follows:

In some countries terms such as "vocational guidance," "vocational counselling," "career counselling," "information, advice and guidance," and "career development" are used to refer to the range of activities that is included here within the term career guidance. In this report career guidance encompasses all of these, and no attempt is made to distinguish between them (Sweet \& Watts, 2004, p. 18).

Consequently, throughout this article the term career guidance will be used to represent all career studies programs, information, education, and guidance that is provided for young people attending compulsory secondary (high-school) education institutions in Ontario.

\section{Career Guidance and Career Studies GLC20 course}

The Ontario Ministry of Education (2013) has described the goals of the education and career/life planning program in Ontario as: (a) ensuring that students develop the knowledge and skills they need to make informed education and career/life choices through the effective application of a four-step inquiry process; (b) providing opportunities for this learning both in and outside the classroom; and (c) engaging parents and the broader community in the development, implementation, and evaluation of the program, to support students in their learning. In order to achieve these goals, the Ministry states that "every elementary and secondary school, under the direction of the principal and with the assistance of key staff and students, will develop, document, implement, and evaluate an education and career/life planning program" (Ontario Ministry of Education, 2013, p. 8).

Within the overarching career guidance curriculum for Ontario public schools, consisting of a number of optional courses, all students are required to take a compulsory half-credit Career Studies (GLC20) course in Grade 10. In this course students reflect on and further develop their individual pathways plan (IPP) by consolidating what they have learned in the four areas of learning: developing self-knowledge, exploring a range of education and career/life opportunities, setting initial post-secondary goals, and developing a plan for achieving those goals (Ontario Ministry of Education, 2013). A high-school teacher might be expected to teach from a range of potential career guidance courses, or concentrate on teaching the GLC20 course. Some schools utilize guidance counselors for teaching GLC20, and some schools employ specific career guidance and or career studies teachers.

\section{Purpose}

The overall goal of this qualitative case study was to describe and understand how one teacher of career guidance courses, in particular the CLC20 course, perceived: (a) the impact of global economic downturn; (b) the impact of changes in the economy, society, 
and job market; and (c) how these changes were reflected in her teaching practice. Therefore, the following questions guided this research:

- What did the teacher's knowledge of the current economic situation contribute to the career education and guidance program?

- How and from where had the teacher gained this knowledge?

- What did the teacher perceive were the particular challenges in the local and wider economy for her student cohort, including youth with diverse needs, in matching their skills with the current labour market?

\section{Theoretical Perspective}

Teachers' experiences of teaching career education and guidance courses in times of significant contextual economic challenge are rarely examined in empirical literature. However, much literature exists from the broader field of career education and guidance, particularly in international, national, and regional contexts. This study contributes to the understanding of how career education and guidance can support STW transition for a diverse range of young people in significantly challenging economic and employment contexts.

\section{Connections Between Career Guidance and the Labour Market}

Career guidance usually reflects a nation's economic, political, social, cultural, educational, and labour market contexts, and the professional and organizational structures in which they operate (Watts, 2000). A goal of the Canadian educational system has been to provide young people with the skills and knowledge they need to succeed in the labour market (Hango \& de Broucker, 2007). Some provinces have shown interest in increasing the career pathways for diverse students, in particular by enhancing the flexibility and mobility in learning systems, by including career planning as part of the secondary-school program, and by highlighting the need for local partnerships between schools, post-secondary institutions, and employers (Taylor, 2007). Frenette (2009) argued that educational requirement knowledge is linked to academic performance and socioeconomic background, and that youth aspirations are often different from the actual distribution of occupations in the economy. This implies that the secondary-school career guidance and GLC20 career studies teacher needs to consider both youths' aspirations and knowledge of current labour market needs in order to help students to see where they intersect.

Bell and Bezanson (2006) concentrated on how Canadian career guidance and development could contribute to students' navigating successful pathways to the labour market. They found that, although there were pockets of excellent and promising practice, many students reported being frustrated with the lack of connection between courses of study and career paths. In addition, some youth were in low-skilled jobs despite their education credentials exceeding job requirements, and some youth were in jobs unrelated to their previously completed fields of study. Bell and Bezanson suggested that though there were pockets of excellent and promising practice regarding career 
education programs, a system of coherent and comprehensive services available consistently throughout Canada simply did not exist.

\section{Structure and Outcomes of Career Guidance and Meeting the Diverse Needs of Youth}

Traditionally career guidance was viewed as a reactive measure, designed to help young people manage transitions from education to work, and to support them in gaining employment (Sweet \& Watts, 2004; Watts, 2005). However, nations have increasingly moved from these earlier models of career guidance to create a more individualized approach that acknowledges increasingly complex economic conditions, youths' personal characteristics, and the lack of educational opportunities, which can constrain successful employment (particularly for youths who do not graduate high school) and exclude some groups of young people (Hango \& de Broucker, 2007; Quintini et al., 2007).

While government statistics focus on unemployment, academic research tends to focus on individuals who are not in education, employment or training (NEETs). Career guidance can be a preventative strategy for NEETs when it helps young people to identify valuable workplace skills that can be learned through the education system (Britton, Gregg, Macmillan, \& Mitchell, 2011). In addition, signposting to credible alternatives to the academic routes is crucial for giving young people most at risk a clear pathway to achievable goals (Roberts \& Atherton, 2011).

Youths' experiences during high school can be significant in helping to prepare them for their future careers (Carter, Trainor, Cakiroglu, Swedeen, \& Owens, 2010). Similar to NEETs, young people with disabilities invariably face more complex challenges than their non-disabled peers (Wehman, 2013). Despite some level of improvement over the past two decades, the vocational landscape for many young adults with disabilities is one of unemployment, underemployment, and segregated employment (Wehmen, 2013). Youth with severe disabilities (i.e., intellectual disabilities, autism, multiple disabilities, or emotional and behavioural disorders) are likely to face substantial challenges in their STW transition. Any career guidance offered in high school can be influential in helping disabled youth to navigate what can be dramatically different pathways to post-school destinations for youth with disabilities. Wehmen described how "the extent to which career development preparation comprises the secondary curriculum of youth can shape the skills they acquire, the resumes they develop, the relationships they build, their engagement in the community, and ultimately, their aspirations for the future" (p. 14).

Educators often describe students whose lack of educational mastery makes their completion of compulsory schooling problematic as "at risk." In the employment sector, the term at risk often refers to individuals who do not have the necessary skills to obtain competitive employment and succeed at their jobs (Cho, Halifors, and Sánchez, 2005; Ziguras, 2006). At-risk youth face a number of barriers regarding workplace readiness and work opportunities, including negative peer associations, adverse personal contexts, and social prejudices, in addition to lacking knowledge and skills (Scarpetta et al., 2010). Portraits of at-risk youth in Ontario (Anisef \& Axelrod, 2001) reveal how individuals who articulate a clear vision of aspirations can "take creative advantage of the enabling 
aspects of social structures" (p. 486), while those who drifted aimlessly are further constrained by social structures.

Despite Canada's relatively strong economy, some Canadian youth are at risk of becoming NEETs and are experiencing educational disengagement and unemployment rates similar to those of their peers internationally (DeLuca et al., 2010). Career guidance can play a vital role in supporting the diverse needs of at-risk and disabled youth, including those who may be at risk of becoming NEET, through directing them to learning that is credible and solidly connected to the workplace (Britton et al., 2011; Scarpetta et al., 2010; Skrzydlewska, 2013).

\section{Career Guidance and the Context in Ontario}

Across Canada, many small communities have been hit hard by the global economic downturn, a factor that further complicates job opportunities for youth. Jinha (2009) examined the economic and social situation of a small town in eastern Ontario, considering the impact of globalization on the town. Jinha reported significant job losses in the town, declaring that by the end of 2008, the town had lost 1,700 jobs, which equated to almost $40 \%$ of its active labour force. Jinha also reported that income levels had declined since 1996, suggesting that the town had struggled economically for some time prior to the global recession that began in 2008. With no public transportation, many new sources of employment being part-time, and non-unionized service jobs, career opportunities for local youth could be significantly limited, complex, and difficult to navigate.

Although the curriculum is subject to regulation within Ontario, there is currently no national career development strategy to provide standards for service quality or provision across Canada (Bell \& Bezanson, 2006) due to the British North America Act of 1867 where it is mandated that education is a provincial responsibility. Within the Ministry of Education's defined curriculum in Ontario, students are required to take a compulsory half-credit course on career studies (called GLC20) during Grade 10. The career education and guidance curriculum also includes a number of optional courses that students can take in grades 9, 10, 11, and 12 (Ontario Ministry of Education, 2006a, 2006b).

The value of career education and career services in supporting youth with the STW transition is widely supported, although the literature acknowledges that some programs seem to be more effective than others (Bell \& O'Reilly, 2008). In this study, I give voice to a teacher located in a school within the catchment area of the town described in Jinha's (2009) study, and report how she navigates the teaching of the GLC20 course in times of global and local economic challenge to meet the individual needs of her students. Her story can help us to understand how career guidance teachers respond to the localized impact of challenging economic conditions that are affecting youth unemployment. 


\section{Method}

\section{Participant School}

Using purposeful sampling, a school was selected for this study. The school was located in an area of eastern Ontario that has been affected by the global recession with the closure of many local businesses. The school included two teachers who taught career studies, one of whom had taught GLC20 for a period that pre-dated the global recession, taught co-operative education, and therefore had links with, and knowledge of, local workplaces. This teacher was willing to share her experience. At the time of the study, the school had a population of approximately 650 students, many of whom were bussed from outlying villages and small towns in eastern Ontario. Initial contact was established with the school, the principal, and the career-studies teacher, who was invited to participate; and full agreement to participate from all parties was obtained. Prior to the collection of data, ethical clearance was obtained from the General Research Ethics Board of Queen's University in December 2010. Confidentiality was addressed through the use of pseudonyms for the participant teacher and school.

\section{Interviews with the Teacher}

This study sought to understand how the teacher of the GLC20 half-credit career studies program translated knowledge about the global and local economic community into her teaching practice. It was therefore essential to hear in her own words how this teacher made sense of the economic community and reached decisions about its relevance to her teaching practice. It was important to understand how contexts might influence the teacher's sense-making process. Herr (1996) agreed "the ecological contexts, in which individuals develop as people, citizens, and workers, significantly influence their possibilities for choice, the knowledge available about opportunities open to them, and the reinforcement of their behaviours" (p. 7).

I employed Bronfenbrenner's (1979) ecological systems theory, which holds that the interaction between or the influences on the teacher's immediate family, community, and work environment, and her wider societal landscape, impacts and directs her career studies program development. Bronfenbrenner (1979) employed his ecological systems theory to explain how an individual's development reflects the influence of several environmental systems, which he classified as microsystem, mesosystem, exosystem, and macrosystem.

The microsystem consists of individual and interpersonal features and aspects of groups that comprise the social identity. This may include the roles that a person plays (for example mother, sister, and employee), characteristics one has in common with others, qualities and characteristics that can be learned from membership in a group, and those that can be ingrained (for example, ethnicity or gender). The individual in his or her microsystems is constantly shaped by both the environment and encounters with other individuals.

Mesosytem refers to organizational or institutional factors that shape or structure the environment within which the individual and interpersonal relations occur (Gregson, 2001). These aspects can include policies, procedures, and more informal rules of "how things are done around here." The four sub-classifications of mesosystem are; Multisetting Participation, which occurs when the same person is engaged in more than 
one setting; Indirect Linkage, when the same person does not actively work in both settings but there is an established connection through a third party; Intersetting Communications, when messages are transmitted from one setting to another; and Intersetting Knowledge, when information or experience exists in one setting about another setting. Examining the participant teacher's knowledge through the layers of the mesosytem enabled a deeper understanding of where she was gaining knowledge to inform her teaching practice.

Exosystem consists of community-level influence, including fairly established norms, standards, and social networks (Gregson, 2001). There will likely be many organizations and interpersonal relationships that comprise this community, and the exosystem is any setting that affects the individual, although the individual is not required to be an active participant. The influences of the macrosystem, for example the participant teacher's knowledge of the current [at the time of this study] Canadian economic situation and government responses, might be seen more easily than the influences of the other of Bronfenbrenner's classifications, due to the magnitude of impact (Gregson, 2001). The macrosystem includes cultural contexts such as socioeconomic status, poverty, ethnicity, and government type and influence.

Bronfenbrenner's ecological system theory provided a multi-layered lens to examine how the participant teacher perceived that government policies and strategies had impacted upon her local and wider community, and what challenges they had presented to her students who were seeking employment. In addition, the teacher's perceptions of the economy, society, and the job market that had translated into her teaching practice were brought into focus. Preliminary reviews of literature and documentation, and my own experience, resulted in the stages of ecological systems theory being applied to the study of the teacher participant in this study, as illustrated in Table 1.

Qualitative interviewing, according to Charmaz (2002), provides an "open-ended, indepth exploration of an aspect of life about which the interviewee has substantial experience, often combined with considerable insight" (p. 676). Framing interviews with Bronfenbrenner's ecological systems theory enabled identification of what the teacher knew about the Canadian and Ontario governments' policies and strategies to respond to the global economic downturn, how these might support her cohort of students, and from where she obtained this knowledge.

Four 45-minute interviews with the teacher were undertaken during school hours over a five-week period (occurring between March and May 2011) based upon an interview instrument, with scope for additional interview questions in the final interview. This time frame allowed the teacher to reflect upon previous interviews and add any additional comments during subsequent interviews. The intention was to establish in the teacher's own words a rich account of her perceptions of: (a) the impact of global economic downturn; (b) the impact of changes in the economy, society, and job market on her teaching of the GLC20 course; and (c) how these changes were reflected in her teaching practice. The teacher was not teaching the GLC20 course during the data collection period of this study; however, she had last taught the course in the preceding semester. Interviews were conducted in a quiet room in the teacher's school and were digitally recorded and transcribed verbatim immediately after the interviews ended. Throughout all interviews, written notes of interviewee responses and non-verbal 
communication were recorded. During the data collection period, I also kept notes of my reflections on the process, recording my observations and any emerging, tentative interpretations immediately after each interview.

Table 1.

Bronfennbrenner's Ecological Systems Theory Applied to Teaching Career Studies

\begin{tabular}{l} 
Ecological Systems Theory Stage \\
\hline Microsystem: The setting in which the \\
teacher lives. Could include a person's \\
family, friends, peers, colleagues, school, \\
and neighbourhood. Where the most direct \\
social interactions take place.
\end{tabular}

social interactions take place.
Possible Areas of Application to the Teacher

- Employment experiences of her family members

- Experiences with colleagues in school-both with regard to their teaching and/or perspective on career studies and their own outside-of-school experiences (e.g., local unemployment)

- Teacher's neighbours' employment status and experience

- Friends that have been affected by changing economy

Mesosystem: A set of interrelations between two or more settings in which the teacher is an active participant.

Bronfenbrenner describes four general types of interrelations; 1) Multisetting participation, which occurs when the same person is engaged in more than one setting. 2) Indirect linkage, when the same person does not actively participate in both settings but a connection is established through a third party. 3) Intersetting communications, messages that are transmitted from one setting to another. 4) Intersetting knowledge, information or experience that exists in one setting about another.

Multisetting participation

- Any other site where the teacher conducts activities related to her teaching, including the responsibilities in Co-operative (co-op) education

Indirect linkage

- Connections that are established through careers studies and co-op teaching practice practice

- Resources

Intersetting communications

- With employers (work experience, co-op placements)

- What form of communication?
- How much co-op practice influences career studies

Intersetting knowledge

- From resources in school (guidance counsellors)

- From relationships with employers

- From local press

- From where else?

Exosystem: One or more settings that do not involve the teacher as an active participant, but in which events occur that affect or are affected by what happens in that setting. To demonstrate the operation of the exosystem as a context influencing the teacher, it is necessary to establish a causal sequence of at least two steps. First, those events in the external system directly connect to processes in the teacher's microsystem; and secondly, linking the microsystems processes to the teacher's developmental changes within that setting.

\begin{tabular}{lll}
\hline Macrosystem: The culture in which the & - & Canada as a developed nation \\
teacher lives and works, including cultural & - & Canada's response to global economic \\
contexts such as socioeconomic status, & downturn-federal strategies and initiatives \\
poverty, ethnicity, government type, and & - & $\begin{array}{l}\text { Ontario's response to economic downturn- } \\
\text { influence. }\end{array}$ \\
& $-\begin{array}{l}\text { Ontario Ministry of Education-strategies, } \\
\text { policies and curriculum }\end{array}$ \\
\hline
\end{tabular}

- Changes to employers-business closures

- Local economic climate changes

- New business start-ups in local area

- District School Board initiatives

- Local demographics 


\title{
Data Analysis
}

A verbatim transcript was produced from each interview. All identifying features of the respondent were removed. Four transcripts were then sent to the teacher participant so she could read and confirm their accuracy. The first two interviews were sent five weeks after completion of the interviews and the final two interviews were sent seven weeks after completion of the interviews. The teacher was invited to comment upon the transcriptions and verify their accuracy, but did not request that any changes be made.

\section{Table 2}

\section{Second Stage Coding-Interview Data Analysis}

\author{
Microsystem \\ - Family (SE) \\ - Colleagues (SE) \\ - Own experience (from previous employment, interaction with media, personal shopping) (SE) \\ - Own expertise (teaching practice, qualifications and training) (SE) \\ - Community (own, immediate) (MC) \\ - Former students (MC and RN)

$\begin{array}{llll}\text { Mesosystem } & & & \\ \text { Multisetting participation } & \text { Indirect linkage } & \begin{array}{l}\text { Intersetting } \\ \text { communication }\end{array} & \text { Intersetting knowledge } \\ \text { - Co-op education } & \text { - Networking (making } & \text { - Employers (RN and } & \text { - In-school resources } \\ \text { practice (SE) } & \text { new connections } & \text { MC) } & \text { (SRT) } \\ \text { - Guest speakers } & \text { through existing links) } & \text { - Wider community } & \text { - Local media (SRT) } \\ \text { (through existing } & \text { (MC) } & \text { (where there is } \\ \text { connections) (SE and } & \text { - Technology (SRT) } & \text { relationship) (RN) } \\ \text { MC) } & \text { - Resources (tools) } & \\ & \text { (SRT) } & \\ & \text { - Post-secondary } & \\ & \text { institution } & \\ & \text { relationships (RN) } & \\ & \end{array}$

\section{Exosystem}

- Local demographics (MC)

- Local economy (includes business start-ups and closures (MC)

- District school board (RN)

- Networking (making connections through new links) (RN)

\section{Macrosystem}

- Global or international (MC)

- Federal (MC)

- Provincial (MC)

- Global or national media (MC)

Note. $\mathbf{S E}=$ Sharing Experience and Expertise; $\mathbf{M C}=$ Making Connections; $\mathbf{S R T}=$ Sourcing Resources or Tools; $\mathbf{R N}=$ Relationships and Networking 
Following the suggestion that "developing some manageable classification or coding scheme is the first step of analysis" (Patton, 2002, p. 463), data were considered against the four classifications of Bronfenbrenner's ecological systems theory as the first stage of analysis, facilitating the search for areas of significance in the raw data. The first cut of this stage of the data analysis was to insert comments into the margins of the transcript, following a deductive approach referring constantly to Bronfenbrenner's classifications. Data were examined and re-examined until I was confident that each of Bronfenbrenner's four classifications had been applied extensively.

In order to deepen my understanding I then undertook an inductive analysis, to create a set of systematic, sensible, and complete categories that would portray the whole picture (Patton, 2002). Table 2 lists the four Bronfenbrenner classifications together with the emerging codes; notes at the bottom of the table describe the key used for each theme. The primary strategy chosen to increase reflexivity was the keeping of field notes and a research journal. It was essential in the writing of this research report that I acknowledged how my own stance shaped my writing (Creswell, 2007). By recording my thoughts and reactions throughout the study and triangulating across sources of data, I was able to add to the rigour of this research.

\section{Interview Data Analysis: Second-Stage Coding from Bronfenbrenner's Ecological Systems Theory (Classifications)}

The completed charts were then further analyzed using an inductive approach, which allowed for clusters of coding categories under each of Bronfenbrenner's classifications to emerge. Possible areas of application to the teacher were previously considered and are shown in Table 1. They provided the starting point for identification of emerging clusters. Data were read and reread to clarify clusters and to identify any additional clusters not represented in Table 1. The clustering process resulted in seven clusters being identified in the microsystem classification, ten clusters in the mesosystem classification (two for multisetting participation, four for indirect linkage, two for intersetting communication, and two for intersetting knowledge). Four clusters where identified in each of the exosystem and macrosystem classifications.

The clusters were then re-examined and arranged according to four overarching themes of (a) sharing experience and expertise, (b) making connections (between different areas of her teaching practice, and using her knowledge to help students make connections through career studies), (c) sourcing resources and tools, and (d) networking and relationships. The findings of the interview data analysis were organized into these four themes, with explicit linkages to Bronfenbrenner's classifications applied across the themes, as shown in Table 3. 
Table 3

Four Themes with Linkages to Bronfenbrenner's Classifications

\begin{tabular}{|c|c|c|c|}
\hline Sharing Experience & Making Connections & $\begin{array}{l}\text { Sourcing Resources } \\
\text { and Tools }\end{array}$ & $\begin{array}{l}\text { Relationships and } \\
\text { Networking }\end{array}$ \\
\hline $\begin{array}{l}\text { Family (MI) } \\
\text { Colleagues (MI) } \\
\text { Own experience (MI) } \\
\text { Own expertise (MI) } \\
\text { Co-op education } \\
\quad \text { practice (MMP) } \\
\text { Guest speakers (MMP) } \\
\text { Employers (MIK \& MIC) }\end{array}$ & $\begin{array}{l}\text { Own community (MI) } \\
\text { Former students (MI) } \\
\text { Guest speakers (MMP) } \\
\text { Networking (MIL) } \\
\text { Employers (MIC) } \\
\text { Local demographics } \\
\quad \text { (EX) } \\
\text { Local economy (EX) } \\
\text { Global or international } \\
\quad \text { (MA) } \\
\text { Federal (MA) } \\
\text { Provincial (MA) } \\
\text { Global or national media } \\
\quad \text { (MA) }\end{array}$ & $\begin{array}{l}\text { Technology (MIL) } \\
\text { Resources (MIL) } \\
\text { In-school resources } \\
\text { (MIK) } \\
\text { Local media (MIK) }\end{array}$ & $\begin{array}{l}\text { Former students (MI) } \\
\text { Post-secondary } \\
\text { institution } \\
\text { relationships (MIL) } \\
\text { Wider community (MIC) } \\
\text { District school board } \\
\text { (EX) } \\
\text { Networking (EX) }\end{array}$ \\
\hline
\end{tabular}

Note . Microsystem = MI; Mesosystem Multisetting Participation = MMP; Mesosystem Indirect Linkage $=$ MIL; Mesosystem Interstetting Communication = MIC; Mesosystem Intersetting Knowledge $=$ MIK; Exosystem $=\mathbf{E X}$; Macrosystem $=\mathbf{M A}$

\section{Results}

\section{Introducing Julia}

At the time of this study, Julia was teaching at Beaver Creek secondary school, a school consisting of approximately 650 students located in a town in eastern Ontario. Julia had been a co-operative (co-op) education, business, and guidance teacher for more than 30 years, and has taught the GLC20 career studies course for more than five years. She had completed the Guidance (part one and part two) Additional Qualifications courses for the province of Ontario, Canada. Julia described herself as having "done a number of other things" apart from teaching, such as working in retail and manufacturing environments, and working part time as a waitress while waiting for her teaching qualifications to be recognized in another jurisdiction. Julia had experienced living and working in another country.

The four themes of (a) sharing experience and expertise, (b) making connections (between different areas of her teaching practice, and using her knowledge to help students make connections through career studies), (c) sourcing resources and tools, and (d) networking and relationships are used to organize the results of the study.

\section{Sharing Her Experience and Expertise}

Julia talked extensively about how she used experience and expertise at the microsystem level within the GLC20 course, making frequent links between her teaching of GLC20 and her teaching of co-operative (co-op) education and business marketing. Julia expanded on how previous work experience had influenced her teaching, as it helped her to identify with kids as individuals and to acknowledge the diverse paths they might take when they completed high school: 
I've worked with a lot of people, you know, I've worked in shops, I've worked in manufacturing, I've worked in warehouses, I've worked as an EA [Educational Assistant] whilst upgrading my qualifications from ... out of county, and, you know, you keep your eyes open and ears open and, and all of that has I think, helped me share some stories (16/04/11: Line 1462).

For Julia, sharing her own and others' experience with students was her way of showing them empathy. Julia described feeling that students were faced with difficult choices about their career and post-secondary destinations, and she felt that sharing her "stories" with students helped to show them that challenges could be overcome. Julia believed that sharing the experiences of others (immediate family and colleagues) also helped her to achieve greater efficiency in the career studies program.

Julia felt that having some expertise in differentiated learning was essential and that the expertise should be underpinned with the right attitude. She talked about "embracing it" and, as part of that attitude, said:

Seeing the intelligences and the extension, what does it mean for half the students or a third of the students to know that they learn in a certain way, they can show you what they know in a certain way, and they can be very productive in certain types of settings and work environments (21/03/11: Line 438).

Julia felt that it was important to be "open to that, and understanding ... having a bit of that knowledge," as "this is an open-level course and you have kids with all kinds of needs."

The concept of attitude also influenced her teaching practice. Julia described how she had "little sayings that I put on the board each day ... building that attitude ... that you are growing and learning all the time." Julia placed importance on sharing this with students and she described how she encouraged them to build upon the "richness of who you are.” However, she acknowledged, “... they can't see what's coming ... that's why we have to give them ... kind of that ... general openness, attitude of general openness." She felt this made students aware of future prospects. Julia described how often her students were "blown away by the opportunities" (04/05/11: Lines 278-285).

Julia talked frequently about the constraints of delivering the GLC20 course over half a semester, and about how using experience and expertise from others helped her to cover a wider range of topics within the curriculum. Julia illustrated how she relied on the experience and expertise of guest speakers within the GLC20 course to help to ensure she covered the curriculum requirements explaining, "There are certain individuals or organizations I bring in because it covers aspects of the curriculum that I don't feel I can adequately cover" (21/03/11: Line 463).

When talking about sharing expertise at the mesosystem level, Julia reiterated the importance of guest speakers as a source of information for the students, telling me, "I bring in a lot of guests that I hope are specialists and will ... bring the students up to speed ... because they [the guests] know what's going on right now" (08/03/11: Line 372). Julia explained how she went about acquiring guest speakers for the GLC20 course saying, "I just pick up the phone and call. I'm used to doing that ... I'm different because I'm a co-op teacher and I know who I would ask and who I wouldn't ask" (21/03/11: 
Line 669). Julia described how it was important that she organized how she used guest speakers, especially any that had not come into school previously, as her students had diverse needs. Julia said:

I have to prepare for that, a new speaker. They need to know what the course is about, because ... they don't understand what the course is about. Who are the kids, how old are they ... what kind of things can I? What kind of things can't I ... shouldn't I say to them? So I give them a bit of an overview ... the course outline ... and ... who the kids are (21/03/11: Line 499).

Julia defined some of the organizations she worked with at the exosystem level in order to source information for her diverse student cohort. She highlighted local Business Improvement Association and Chamber of Commerce resources that she used: "Those are the people I talk to ... and they will come into your class as well ... to give discussions ... Also for me, just going in there and picking up brochures and information and seeing what's going on" (16/04/11: Line 531). Julia described how important it was that she understood where to source job-related support for her students, especially given that many of them "need jobs, you know, they need to help to support their families" (16/04/11: Line 327).

\section{Making Connections}

Making connections had become important for Julia because she felt it allowed her to access the right information from the right people in order to meet the diverse needs of her students. Julia also described how it was important for her students to make connections. Julia referred to the necessity of students being able to "connect the dots" between their learning, the requirements of the GLC20 course, and students' future learning, training, or work aspirations.

When asked about what she knew of how the global economic downturn had impacted upon the local and wider communities, Julia described how the microsystemlevel experience of "living in the community" was a source of her knowledge, "just driving around and looking around in my ... community ... it's very small business, it's what it's all about ... very few large organizations out here" (21/03/11: Line 1083). Julia talked about how her visits to the local Business Improvement Association and Chamber of Commerce helped her to keep up to date with what was happening with local businesses: "I am looking for opportunities for placements for my students but it also keeps me abreast of ... the new ... emerging [business and trade]... it is all about small business here" (16/04/11: Line 552).

Julia explained that making connections was particularly important for students to see relevant opportunities beyond high school: "You know, some students, they are just not academic right? Running their own business is a good option for them" (16/04/11: Line 324). Julia highlighted that mesosystem-level guest speakers, including those from the Ontario Summer Company, were a great source of expertise that informed her teaching; and she noted that as an organization the Summer Company was "a huge part of our economy in Eastern Ontario ... encouraging youth who want to start a business, and supporting them through a summer program" (08/03/11: Line 926). 
Furthermore, Julia explained how she felt that parents needed to know more at the mesosystem level about what the career studies program could do for their kids. "I would give them a bit more information of where we're going ... I would perhaps tell the parents a little of what the students are going to get in the course" (08/03/11: Line 122). Julia believed that parents can be more informed than their children who are in Grade 10, especially about apprenticeships. "The parents know ... what apprenticeship is, a lot of the students don't even know what that is yet ... I can presume more knowledge on the parents' part" (08/03/11: line 174). However, Julia also described how she felt that parents needed to be shown how to make connections between the courses being taken by students and varied post-secondary planning, "the key [is] ... that they [parents] understand the best maths [open, applied, or academic level], for programs and career directions and destinations, whether it's college, or apprenticeship ... university" (08/03/11: line 201).

When asked about the impact of macrosystem-level global economic downturn on businesses in her local community, Julia responded, "I know that the pressure's on everybody ... they have less time to do what they need to do ... every organization is cutting staff and so forth ... I see everybody trying to do what they've always done ... with less" (21/03/11: Line 928). Julia was also able to highlight a direct impact this had upon the career studies program: "I've heard that one of the universities cut the Grade 10 career studies program [no longer making visits to her school to discuss post-secondary options with Grade 10 students]." She also described how she had lost a valued guest speaker. "There's one business that no longer exists ... there was somebody from that organization that used to come in and speak ... and that business is not here" $(21 / 03 / 11$ : Line 937). Julia explained how the person who came in had "retired from another field and gone into this field ... those are the valuable ones, when they can talk about a couple of different things ... he was valuable ... and the business is gone, he's gone" $(21 / 03 / 11$ : Line 939).

Responding to being asked about macrosystem-level provincial responses to the global economic downturn, Julia confirmed how one nearby town in the catchment area of her school had been hit hard: "Two huge employers ... have shut down" (16/04/11: Line 441). Julia did not feel that there had been a specific provincial-level response to situations like the one in her local town; she did know that "there was some re-training." Julia described the stress this had placed upon the area saying, "In terms of manufacturing positions ... I don't know where these people are working or what they are doing ... I think it must be difficult ... a lot of our kids, that's our catchment area" (16/04/11: Line 476).

Julia highlighted how, since the macrosystem-level global economic downturn, she felt that the attendance at breakfast club in school had risen. "All it takes is going in and looking at the breakfast program downstairs and see how much food we feed the kids here ... at breakfast and lunchtime and ... those kids are hungry" (16/04/11: line 861). Julia reported feeling that many teachers "don't hear enough about ... our specific kids ... I do ... because I am a co-op teacher ... I really get ... inside the lives of those kids" (16/04/11: Line 427). 


\section{Sourcing Resources and Tools}

Julia explained how at the microsystem level, locating the right resources were important to her GLC20 course teaching, in particular her use of internet resources. Resource availability was often an issue, and Julia discussed how the loss of governmentproduced literature had impacted upon her teaching. Julia clarified the necessity of resources being available in electronic format, allowing for her to adapt resources easily to meet the needs of her students. Constraints of delivering the GLC20 course over half a semester caused Julia to be selective in using tools and resources, and encouraged her to reuse resources that she felt had worked well previously.

Identifying in-school resources at the mesosystem level, Julia described books she used: "I've got a class set ... with authentic work place ... numeracy and ... text pieces from different careers ... so they're authentic ... work place documents that a person might [be] running across if you were ... a shop clerk for instance" (04/05/11: Line 1272). Julia explained how it was valuable for the students to "take a look" and for the students to find examples they can use to "try to find information." Julia described how many students often need guidance and support with this, and how she encouraged them to think about "[what] would you be looking for ... if you were looking for pharmacist's aide ... and ... the technical language and things like that" (04/05/11: Line 1281). Julia added that she felt it was important for students to be given these types of activities. "Again it's exposure to connect the dots" (04/05/11: line 1283).

Julia also talked about the necessity of adjusting some activities at the mesosystem level, "I tone them down ... sometimes these activities are a little bit too ... academic maybe for them" (04/05/11: Line 732). Julia explained that electronic resources made it easier for her to do this, adapting resources for use in an open-level course. Julia explained the necessity for resources and tools to be available in electronic format so that she could adapt them to meet the needs of a diverse range of students. Resources and tools were most useful to Julia when she was able to use them to help her activities "come to life" making the GLC20 course more realistic for her students.

Julia reported picking up knowledge from the macrosystem level, for example, "CBC is great, sometimes CBS ... and local news as well" (16/04/11: line 499). Julia said, "I know from listening to the radio that ... our job statistics aren't great, and in eastern Ontario they're not great ... particularly for youth." Julia added, "I can't quote the numbers but I know last week there was a lot of discussion ... around an article that came out about suicide and depression in children, or youth." Julia explained that the article had the "link being made to job prospects ... and so forth and kids feeling trapped ... without a lot of opportunities" (16/04/11: Line 347).

Drawing on a recent conversation with her daughter, who was living and working in Australia, Julia spoke wistfully about the idea of using "smart boards and internet access [opening up new macrosystem-level geographical sources of information through Skype]," and added, "We should just Skype, you know we should have a session with you talking to the students about marketing in travel and tourism in ... Australia, and the wonderful opportunities and gee that would be so cool" (04/05/11: Line 839). Julia felt that this possibility was "right there at our fingertips"; however, she acknowledged, "[only] when the technology is working," describing how in the past she had been 
timetabled to teach career studies in a portable classroom "where there is no technology at all" (04/05/11: Line 911).

\section{Relationships and Networking}

Julia spent considerable time networking to support her GLC20 course teaching. Recognizing, creating, and acting upon opportunities at the mesosystem level to obtain guest speakers was a large part of her preparation; she spoke of the need to constantly be aware that guest speakers "come and go." Julia described how important it was that she could "trust" the guest speaker, and the content they would present to the students, as she needed to be confident that the students would be given the "right information" (16/04/11: Line 298). Detailing how guest speakers volunteered their time, Julia explained how they were much more willing to come and speak to the students if they had built a relationship with her first. Julia described the enormous challenge of working at micro- and mesosystem levels with such a variety of guest speakers, especially given the diverse needs of her students. "Building those relationships, that trust, it's just so important" (16/04/11: Line 301).

\section{Discussion}

The interview data showed that Julia saw a connection between macro-level policies and strategies and an impact in her local community. Even though she was unable to name specific government policies and strategies, Julia talked about initiatives she had seen in her local community and recognized these as part of government response to economic downturn. Julia emphasized the importance of her students' also being able to make these connections and relied on the up-to-date knowledge of guest speakers in the career studies program to help her achieve this. Julia showed awareness of the limits of her own knowledge but this was reconciled with her feeling that this was "OK...because I'm aware that it's huge and it's changing all the time." Julia had limited knowledge of federal and provincial policies and strategies, though she acknowledged their existence and saw that they were connected to the career studies curriculum. The demands of her teaching roles meant that Julia had limited opportunity to extend her knowledge of these topics.

Julia's knowledge came almost entirely from microsystem and mesosystem levels. At the microsystem level, Julia relied upon her own experience and expertise, the experience and expertise of colleagues, and her own knowledge of the local community. At the mesosystem level, the data revealed that Julia used guest speakers, networking with post-secondary providers, her other teaching roles, and her role within her local community to source information about relevant macro-level policies and strategies. These sources were available to Julia within her normal teaching roles and within her normal daily routines; however, Julia did not seek additional sources.

Julia felt students were susceptible to conflicting advice from school and parents when it came to making choices that would impact upon their future career paths. Julia described situations in which she felt parents did not understand either the requirements of the curriculum, or which programs would be most suitable for their children's 
academic capability. Julia knew the local economy had been affected by the global economic downturn and described local business closures. Julia understood the consequent impact upon the students at her school. She described increased use of her school's breakfast club, saying, "Those kids are hungry." Julia linked this with high unemployment in a nearby town, explaining how the location of the affected town was in her school's catchment. The data showed Julia's awareness of local demographics, and subsequent influence upon local businesses and services. Julia explained feeling how important it was that students understood these types of connections. Julia discussed the students' challenges in general terms, but she did not make links to specific challenges in the labour market.

For Julia, residing in her school's local community, together with her role as a cooperative (co-op) education teacher in this community, were the primary microsystem and mesosystem sources of knowledge and information that informed her work in the career studies program. The data also highlighted how Julia frequently shared experience and expertise (at mircrosystem level) with colleagues about local and wider community issues, and Julia described the importance of being "open to this." The local media was a further mesosystem-level source for Julia, sometimes through her direct interaction, and sometimes through listening to colleagues' descriptions of local community issues reported. Julia rarely sourced information at the macrosystem level about future employment challenges faced by her students.

Julia's knowledge of the economic situation and related challenges presented to her local and wider community influenced her teaching of the career studies program in a number of ways. Julia reflected on how her experience and expertise affected her attitude toward teaching the program. Her knowledge of the current context and its challenges informed Julia's discussions with students about local career opportunities.

Julia used knowledge of macrosystem-level issues to inform her teaching practice but she did not source knowledge from macrosystem-level sources. Instead, she relied on the microsystem level through utilization of her own experience and expertise and that of her colleagues. She also used mesosystem- and exosystem-level sources, depending on the use of guest speakers and networking with post-secondary institutions. Consistent with the findings already discussed, Julia relied on her daily encounters to inform her work in career studies.

\section{Implications}

This study was conducted in a small rural town in eastern Ontario. The results of this study might have looked very different if conducted in another area within Ontario. A teacher located in a dense urban area (e.g., Toronto) would be exposed to a greater diversity of cultural backgrounds and experiences within their student cohort, colleagues, peer groups, and local business demographics. It would also be useful to undertake additional case studies with career studies teachers that teach coop education. This would help to create a clearer picture of how the two teaching roles can complement and support each other. Julia's role as sense maker of the career studies program has implications for the career studies curriculum as a form of 
policy. Coburn (2001) noted a promising new strand of research in the mid 1990's that pointed to teacher's professional communities as important sites for making meaning, highlighting the ways in which local teacher communities can form powerful microcultures. The data in this study demonstrated how Julia had networked and formed relationships with colleagues and guest speakers, which she used to source experience and expertise, and to begin to form her own microculture. Policy could be used to extend the ways career studies teachers are able to participate in these types of collaborative microcultures, and provide greater access to knowledge resources. This would be particularly useful for career studies teachers who do not have complementary teaching subjects like co-op education that lend themselves to creation of microcultures. A further consideration for compulsory career studies programs that comprise half-credit courses is to consider extending the program to become a full-credit course. Teachers would then have far greater flexibility to follow Herr's (2003) recommendations that "resources should be used to build tailored, effective, and evidence-based responses to the career needs that are represented" (p. 15).

Carter et al. (2010) outlined how administrators, guidance counselors, student services, educators, and others might automatically assume that all youth within their school enjoy identical and equitable access to career guidance activities within their school. The curriculum documents (Ministry of Education, 2006a; 2006b) provide guidance for the GLC20 teacher for meeting the needs of students with Special Educational Needs. However, the guidance is brief and largely focused on advising teachers how to establish whether a student needs accommodations for the career studies course, how to meet the requirements of a student's Individual Education Plan, and how to undertake assessment should a student require modified expectations. I would contend that with such limited guidance available for GLC20 teachers, we should not assume appropriate and equitable access to career guidance exists.

This study highlights just one teacher's story, and I would suggest undertaking additional studies to further identify how effective GLC20 experiences link with positive outcomes for youth, specifically youth with diverse needs. In particular, I suggest that further research should explore the experiences of participating in the GLC20 course from both the educators' and the students' perspectives. Such research should examine the delivered and experienced curriculum of both career studies teachers and students, with a particular focus on minority, at-risk, immigrant, aboriginal, and disabled youth, including young people with exceptionalities. The findings of this study highlight the importance of strengthening efforts to provide all high-school students with experiences and meaningful opportunities that will support and prepare them for STW transition. 


\section{References}

Anisef, P., \& Axelrod, P. 2001. Baby boomers in transition: Life course experiences of the 'class of '73.' In V. W. Marshall, W. R. Heinz, H. Kruger, \& A. Verma (Eds.), Restructuring work and the life course (pp. 473-488). Toronto, ON: University of Toronto Press.

Bell, D., \& Bezanson, L. (2006). Career development services for Canadian youth: Access, adequacy and accountability. Ottawa, ON: Canadian Policy Research Networks.

Bell, D., \& O'Reilly, E. (2008). Making bridges visible: An inventory of innovative, effective or promising Canadian school-to-work transition practices, programs and policies. Ottawa, ON: Work and Learning Knowledge Centre.

Britton, J., Gregg, P., Macmillan, L., \& Mitchell, S. (2011). The early bird: Preventing young people from becoming a NEET statistic. Retrieved from University of Bristol Centre for Market and Public Organisation website: http://www.bristol.ac.uk/cmpo/publications/other/earlybirdcmpo.pdf

Bronfenbrenner, U. (1979). The ecology of human development: Experiments by nature and design. Cambridge, MA: Harvard University Press.

Carter, E. W., Trainor, A. A., Cakiroglu, O., Swedeen, B., \& Owens, L. A. (2010). Availability of and access to career development activities for transition-aged youth with disabilities. Career Development for Exceptional Individuals, 33(1), 13-24.

Charmaz, K. (2002). Qualitative interviewing and grounded theory analysis. In J. F. Gubrium \& J. A. Holstein (Eds.). Handbook of interview research: Context and method (pp. 675-694). Thousand Oaks, CA: Sage.

Cho, D., Halifors, D., Sánchez, V. (2005). Evaluation of a high school peer group intervention for atrisk youth. Journal of Abnormal Child Psychology, 33(3), 1832-1849.

Coburn, C. E. (2001). Collective sensemaking about reading: How teachers mediate reading policy in their professional communities. Educational Evaluation and Policy Analysis, 23(2), 145-170.

Creswell, J. W. (2007). Qualitative inquiry and research design: Choosing among five approaches. Thousand Oaks, CA: Sage Publications.

DeLuca, C., Hutchinson, N. L., deLugt, J. S., Beyer, W., Thronton, A., Versnel, J., Chin, P., \& Munby, H. (2010). Learning in the workplace: Fostering resilience in disengaged youth. Work, 36(3), 305-319.

Department of Finance Canada. (2010). Canada's economic action plan: Canada's global economic leadership. Retrieved from http://www.fin.gc.ca/pub/report-rapport/2010-6/cgel-lemc2eng.asp

Frenette, M. (2009). Career goals in high school: Do students know what it takes to reach them, and does it matter? (Report no. 11F0019M-320). Ottawa, ON: Statistics Canada.

Gregson, J. (2001). System, environmental, and policy changes: Using the social-ecological model as a framework for evaluating nutrition education and social marketing programs with lowincome audiences. Journal of Nutrition Education, 33(1), 4-15

Hango, D., \& de Broucker, P. (2007). Education-to-labour market pathways of Canadian youth; Findings from the youth in transition survey (Report No. 81-595-MIE-054). Ottawa: Culture, Tourism and the Centre for Education Statistics.

Harper, S. (2010). Government Priorities, (para. 1-5). Retrieved from http://www.pm.gc.ca/eng /feature.asp?featureld $=4 \&$ page $I d=123$

Herr, E. L. (1996). Perspectives on ecological context, social policy, and career guidance. The Career Development Quarterly, 45(1), 5-19. 
Herr, E. L. (2003). The future of career counselling as an instrument of public policy. The Career Development Quarterly. 52, 8-17.

Jinha, A. E. (2009). Smiths Falls in the world: A study of globalization in a rural Canadian town. Just Labour: A Canadian Journal of Work and Society. 14(3), 96-113.

Kelly, T. (2010, March 9). Plans unfolding to bring people and businesses to Smiths Falls. YourOttawaRegion.com. Retrieved from http://www.yourottawaregion.com/print/628237

McCarthy-Fry, S. (2009). Ministerial foreword. In Department for Children, Schools and Families, The work-related learning guide (2nd ed.) (p. 5). Reference publication number DCS004172009. Retrieved from http://dera.ioe.ac.uk/10591/1/Work-related_learning.pdf

Ontario Ministry of Children and Youth Service. (2008). Realizing potential: Our children, our youth, our future (Strategic Framework 2008-2012). Retrieved from http://www.gov.on.ca /children/english/minsitry/strategic/index.html

Ontario Ministry of Education. (2006a). The Ontario curriculum grades 9 and 10. Guidance and career education (revised 2006). Retrieved from http://www.edu.gov.on.ca /eng/curriculum/secondary/guidance.html

Ontario Ministry of Education. (2006b). The Ontario curriculum grades 11 and 12. Guidance and career education (revised 2006). Retrieved from http://www.edu.gov.on.ca /eng/curriculum/secondary/guidance.html

Ontario Ministry of Education. (2013). Creating pathways to success, an education and career life planning program for Ontario schools: Policy and program requirements, kindergarten to grade 12. Retrieved from http://www.edu.gov.on.ca /eng/document/policy/cps/CreatingPathwaysSuccess.pdf

Organisation for Economic Co-Operation and Development (OECD). (2004). Careers guidance and public policy: Bridging the gap. Paris, FR: OECD.

Organisation for Economic Co-Operation and Development (OECD). (2009). Employment outlook: Tackling the jobs crisis. Paris, FR: OECD.

Patton, M. Q. (2002). Qualitative research \& evaluation methods (2nd ed.). Thousand Oaks, CA: Sage Publications.

Quintini, G., Martin, J. P., \& Martin, S. (2007). The changing nature of the school-to-work transition process in OECD countries (No. IZA DP No. 2582). Bonn, Germany: Institute for the Study of Labor (IZA).

Roberts, K., \& Atherton, G. (2011). Career development among young people in Britain today: Poverty of aspiration or poverty of opportunity. International Journal of Education Administration and Policy Studies, 3(5), 59-67.

Scarpetta, S., Sonnet, A., \& Manfredi, T. (2010). Rising youth unemployment during the crisis: How to prevent negative long-term consequences on a generation? (OECD Social, Employment and Migration paper No. 106). Paris, FR: OECD.

Skrzydlewska, J. K. (2013). Draft report on tackling youth unemployment: Possible ways out. Brussels, Belgium: Committee on Employment and Social Affairs, European Parliament.

Sweet, R., \& Watts, A. G. (2004). Career guidance and public policy: Bridging the gap. Paris, FR: OECD.

Taylor, A. (2007). Pathways for youth to the labour market: Canadian Policy Research Networks project. Ottawa, ON: Work and Learning Knowledge Centre.

Watts, A. G. (2000). Career development and public policy. The Career Development Quarterly, 48, 301-312. 
Watts, A. G. (2005). Career guidance policy: An international review. The Career Development Quarterly, 54, 66-76.

Watts, A. G., \& Sultana, R. G. (2004). Career guidance in 37 countries: Contrasts and common themes. International Journal for Educational and Vocational Guidance, 4(2-3), 105-122.

Wehmen, P. (2013). Transition from school to work: Where are we and where do we need to go? Career Development and Transition for Exceptional Individuals, 36(1), 58-66.

Ziguras, S. (2006). Labour market transitions and risks of exclusion. Australian Bulletin of Labour, $32(3), 203-226$.

\section{Author's Note}

Correspondence concerning this article should be addressed to: Lorraine Godden, Queen's University Faculty of Education, Duncan McArthur Hall, 511 Union Street, Kingston, ON, K7M 5R7, Canada. Email: lorraine.godden@queensu.ca 